\title{
INTERACTIONS WITH LOW WAGES: THE AUSTRALIAN APPROACH TO WORK BENEFITS
}

\author{
Sarah Wilkin and Jocelyn Pech
}

Australian Fair Pay Commission Secretariat

\begin{abstract}
It is not always well understood that Australia has a comprehensive set of social security arrangements with the potential to significantly supplement low wages, especially for families with children. These provisions have evolved over a long period, beginning with the introduction of child endowment in the 1940s. During the past twenty-five years, the coverage of income transfers as a supplement to earnings has been significantly expanded, such that it now provides support for partners as well as for children and, in some cases, for low-paid full-time workers themselves.
\end{abstract}

The Australian approach differs in a number of ways from approaches typically taken in other countries. This paper outlines how the Australian system of wage supplementation has evolved over the last century. It charts the evolving relationships between the income support system and minimum wages and highlights the influence of key policy changes on those relationships and the consequent financial incentives to take low-paid work.

In conclusion, the paper reports recent evidence from the OECD which finds that Australia and New Zealand are among a small group of countries that consistently provide higher relative incomes for low-wage earners than comparable arrangements in most other developed countries.

\section{Introduction}

At the core of the Australian social protection system is the social security system administered by the Australian Government. This provides flat-rate income support payments to categories of people who are either not expected to work, unable to work or unable to find work. There are additional payments for a variety of special needs (for example, rent assistance for people paying private rent) and for people with dependent children.

Other elements of the broad social support system include retirement and disability pensions; a mix of compulsory and voluntary occupational superannuation; the health care system, based on the national health insurance scheme, Medicare; workers' compensation arrangements; paid sick leave funded by employers; and other cash and in-kind welfare benefits and services, such as subsidised child care, public housing and transport (Whiteford and Angenant 2001, pp. 7-8).

Government income support has a long history in Australia, from Federation (1901) to the present. It is said to be underpinned by two objectives: first, the recognition of government and community responsibility to assist those in need; and second, that private provision outside the social security system is to be encouraged as far as possible (Whiteford and Angenant 2001, p. 13).

The primary purpose of the Australian income support system, therefore, is to function as a safety net for people in need. This distinguishes Australia from most other developed countries (apart from New Zealand), where the primary principle is one of income maintenance across an individual's life cycle - as opposed to relief from financial hardship.

Unlike in most other developed countries, Australia's income-support system is not funded by social insurance. The comprehensive system of payments is noncontributory and financed from general revenue. With limited exceptions, payments are means-tested by reference to income, and in many cases also to assets.

In addition to the social safety net, Australian workers are protected by the Australian labour market and workplace relations institutions. The current legislation provides a combination of legislated minima and industrial instruments covering minimum wages and conditions of employment. In relation to minimum wages WorkChoices introduced the Federal Minimum Wage and retained components of the previous hierarchical award wages with the creation of Australian Pay and Classification Scales - establishing minimum wage rates below which no Australian worker in the federal jurisdiction may be paid.

Australia is relatively unusual among developed countries in that families on low wages frequently have their income augmented through general income support and family assistance payments, as opposed to specific inwork benefits. Other countries tend to have specific programs available only for people in work (for example, the Earned Income Tax Credit in the United States) or a parallel program for people in work that operates alongside their general social assistance program (for example, the Working Families Tax Credit in the United Kingdom). 
In Parts 2 and 3 of this paper, respectively, we outline how the Australian systems of minimum wages and income supports for low-paid workers have evolved over the last century. In Parts 4 and 5, we chart the evolving relationships between the social security system and minimum wages and describe the current interactions between wages and transfers. Finally, in Part 6, we summarise recent evidence from OECD cross-national studies which shows that the Australian combination of minimum wages and income transfers provides better relative outcomes for the lowest paid worker than those in almost any other country.

\section{A brief history of Australian statutory minimum wages}

Before WorkChoices, there had never been one Federal minimum wage set by legislation in Australia. However, since the early years of Federation (1901) and up to 2005, the Australian Industrial Relations Commission and its predecessors set the wages of workers covered by awards. This wage-fixing process became centralised through national wage cases and after the introduction of formal workplace-level bargaining in the 1990s the AIRC continued to determine award wage minima through the annual Safety Net Reviews. These wage decisions usually flowed also to state awards.

\section{Before 1945}

In the latter half of the nineteenth century, the concept of a 'basic' or 'living wage' began to gain currency. In 1907 , in the celebrated 'Harvester Judgment', Higgins J expounded the notion of a 'fair and reasonable wage' as that which would be necessary to sustain an average employee in 'a condition of frugal comfort estimated by current human standards'. The employee to whom this standard should apply was assumed to be an unskilled male worker (breadwinner) with a dependent wife and three children (Hancock 1979b, p. 130). This judgement supported the then-prevalent notion than welfare outcomes should be achieved by wage-related benefits rather than tax assistance or social welfare, either in cash or kind (Australian Treasury 2008, p. 195).

The following structure emerged in the aftermath of the Harvester judgment: a basic wage common to all male workers irrespective of the work upon which, or the industry in which, they were employed; and a secondary wage or 'margin for skill, responsibility, or particular circumstances of the work or industry in question'.

Towards the end of World War II, the principle of the basic or living wage was extended to women. However, unlike for men, the female needs benchmark was for a single woman with no dependants. This approach resulted in a female wage of around 50 to 55 per cent of the male rate (gradually increased in following years to 75 per cent).

Throughout the $1920 \mathrm{~s}$, the basic wage was adjusted periodically to take into account increases in the cost of living (in practice, however, lags often meant a decline in real value). During the 1930 s and 1940 s, there was a marked change in emphasis with greater explicit account taken of the capacity of the employer to pay. Instead of focusing primarily on the needs of the workers, wagesetting bodies ${ }^{2}$ began to look more to how those needs were to be judged within the broader national context (Owens and Riley, p. 291).

\section{5 to 1974}

The concept of a basic wage plus margins for skill prevailed until the late 1960 s when it was overtaken in the 1967 National Wage Case by the concept of the 'total wage'. It was during this time that the concept of 'minimum wages' was introduced, with the Commission defining its role as setting the minimum award rates that should be paid, as opposed to the maximum or average rates.

A series of National Wage Cases between 1969 and 1974 addressed the by then contentious issues of the 'family wage' and gender equity. In its decision on the 1974 National Wage Case, the Commission stated its intention to discard the family component from the minimum wage concept, emphasising also that it was an industrial arbitration tribunal, not a social welfare agency, and that the care of family needs was principally a matter for governments (Nieuwenhuysen 1974, p. 285).

\section{$1980 s-1990 s$}

Indexation of minimum wage increases ended in 1981 and a minimum wages pause was introduced in 1983. From 1983 to 1993 , the principal focus in wage fixing was upon controlled minimum wage increases determined by reference to increases in the cost of living and in national productivity - the Accord.

There was also increasing support for wage determination at the level of the enterprise or the workplace. In 1993, the Keating Labor Government signalled a major policy change in industrial relations that subordinated centralised wage fixing to enterprise bargaining. The Industrial Relations Reform Act 1993 (Cth) made it clear that there was a distinction between the arbitrated award safety net and the bargaining stream, with the then Prime Minister Keating stating that it placed

primary emphasis on bargaining at the workplace level within a framework of minimum standards provided by arbitral tribunals...(and)...under which compulsorily arbitrated awards and arbitrated wage increases would be there only as a safety net [emphasis added] (Australian Industrial Relations Commission 2005, p. 7).

Over this period, minimum wages came to be seen more as part of a formal 'safety net' of basic terms and conditions of employment which underpinned the operation of the formal enterprise bargaining process. 


\section{6 to present}

In 1996, reforms by the Howard Liberal/National coalition government culminated in the Workplace Relations Act 1996 (Cth) (WR Act). The object of the WR Act authoritatively established the function of minimum wages to provide for an effective award safety net of fair and enforceable minimum wages and conditions of employment.

In the late 1990 s and early 2000 s, there was some debate, initiated by the 'Five Economists ${ }^{3}$ on whether staged reduction of minimum wages, in conjunction with improvements in the tax-transfer system, would create jobs and reduce unemployment (Dawkins 1999, 2002: Borland 2002). However this proposition was disputed by some economists and there was also concern about the effect such a course might have on low-income households (Richardson and Harding 1999, p. 25: Apps 2002a. b).

In 2006, the Australian Fair Pay Commission was established under the Howard Government's WorkChoices legislation to replace the wage-setting functions of the Australian Industrial Relations Commission. $^{4}$ After election of the Rudd Labor Government in late 2007. the Fair Work Bill 2008 proposes to transfer this function to Fair Work Australia in 2010 ,

\section{Development of the Australian income transfer system in relation to low-paid workers}

The Australian income transfer system has, like the labour market, changed significantly since the end of the nineteenth century. Since the early days of Federation, transfers have evolved from basic pension payments for old age, disability and war service to a more extensive system of social support, which in many cases provides income supplementation for wage-earning households. What follows is a brief history of the development of the main payments that in the $21^{\text {st }}$ Century provide support for dependent children, dependent partners and low-paid workers themselves.

\section{Assistance for dependent children}

As stated earlier, the 1907 'Harvester' family wage was originally assumed to provide adequate support for a wife and children (a family of 'about five' in the original decision). For many years, therefore. it was not considered necessary to provide additional support to meet the needs of low income workers with families to support.

The earliest form of family assistance provided by the Commonwealth Government was a lump-sum non-meanstested maternity allowance, introduced in 1912. This was followed by the introduction of child endowment in 1941 (Kewley 1969, pp. 6, 78-80).

The earliest proposal for child endowment had been made by the 1920 Royal Commission on the Basic Wage, on the argument that the basic wage was inadequate to support a whole family (Hancock 1979b, pp. 133-134; Hancock 2004). Limited schemes had been introduced in 1920 for Commonwealth public servants and in 1927 for families in New South Wales (Kewley 1969, p. 69). The introduction of the national scheme of child endowment could be regarded therefore as the first official acknowledgement that the 'Harvester' basic wage might be insufficient to support a family with more than one child. $^{5}$ Significantly, this early assistance was targeted towards all families with children, including families receiving income support, rather than to working families.

Over the years following its introduction, rates of child endowment were increased only sporadically (FaCSIA 2006, p. 128) and its value fell significantly in real terms. As early as 1949 , higher rates of assistance were provided for families receiving income support, so that by 1972 a pensioner or beneficiary with three children received almost five times as much in child-related assistance as a working family with three children (FaCSIA 2006, pp. $122,125,128)$

In 1976, the final report of the Henderson Poverty Inquiry recommended the abolition of tax concessions for dependent children and an increase in the rate of Child Endowment in order to redirect assistance to poorer families. especially those in paid work. The Fraser Government acted on this recommendation in 1976 by combining child endowment and tax rebates for dependent children into a comprehensive system of family allowances. This effectively increased the level of assistance for low-income working families with children, many of whom had not paid sufficient tax to benefit from the full value of the previous tax rebates (Kewley 1980, pp. 97-101).

Despite economic growth, high levels of unemployment and inflation persisted into the late 1970s and early 1980s. There was increasing concern about the relativities between unemployment benefits and wages, particularly in the case of large families, where the value of unemployment benefits could exceed disposable income available through the combination of minimum wages and child endowment.

This led to the introduction in 1983 of the Family Income Supplement (FIS), which provided low-income working families with child-related payments equivalent to those available to social security pensioners and beneficiaries. The objective of the payment was to ensure that such families would always have more disposable income in employment than in unemployment. FIS was later expanded and transformed into Family Allowance Supplement as part of the family allowance reforms introduced by the Hawke Labor government in 1987.

Family Tax Benefit (FTB) was introduced in 2000 as part of a package of reforms accompanying the introduction of the goods and services tax. Rates of payment were increased and the income test was liberalised at that time and a number of times in subsequent years. 
Figure 1 illustrates in diagrammatic form how the system has evolved since the introduction of child endowment and additional pension in 1941. Since very early on, Australia has had two streams - a basic payment for (now almost all) families with children and additional payments for the children of income support recipients. These two were joined in 1983 by the in-work stream which was then combined with additional pension and benefit in 1993. That basic architecture can still be seen in the simpler structure of Family Tax Benefit.
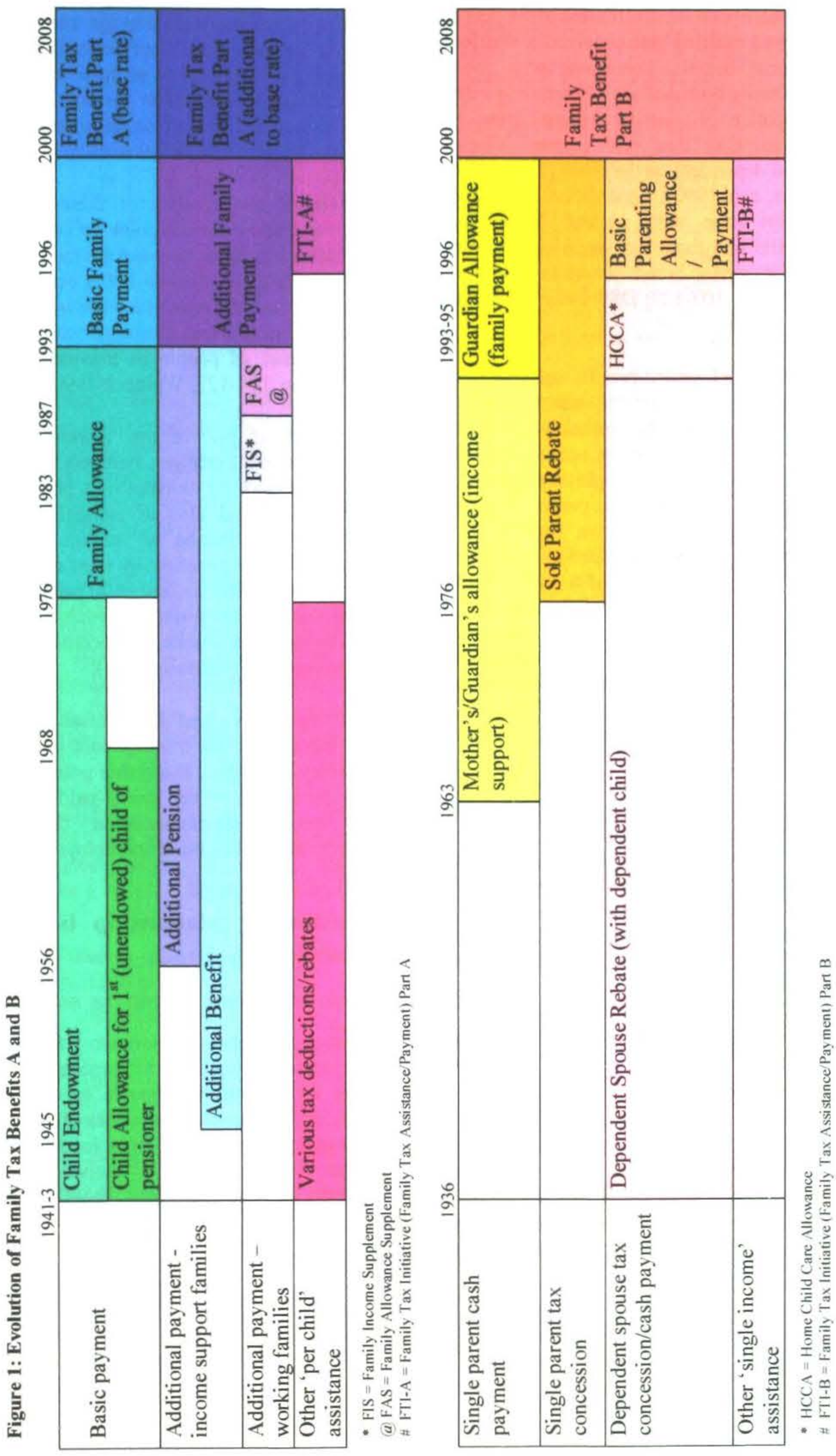


\section{Support for dependent spouses}

Changing social perceptions about the role of women in the labour force have also changed the way the Australian social security system treats dependent spouses.

Before 1995, wages were presumed sufficient to support a spouse and unemployed married men received a married rate of unemployment benefit, consistent with their assumed role as the family breadwinner. However, as the labour force participation of married women grew, it challenged the assumption that one partner should naturally be presumed dependent on the other (Cass 1988, pp. 227-240; Douglas, et al 1993). In addition, minimum wages had not kept pace with income limits for unemployment benefits and there was growing concern over the incentives for married breadwinners to take lowpaid work (Cass 1988, pp. 107-127; DSS 1993; Whitlock 1994).

In 1994, the married unemployment benefit was split into two parts, with one half paid to the unemployment beneficiary and the other to his or her spouse in the form of a partner allowance. Further changes occurred in the following year, when the married unemployment benefit was fully disaggregated, so that each partner had to qualify for income support in their own right. This change was accompanied by the introduction of a new parenting allowance, for one member of a couple with dependent children under 16, and new income-testing arrangements for couples. These aimed to ensure that while both were on payment, each had their entitlement assessed on their own income, with a partner's income taken into account only once it was sufficient to preclude the payment of their own allowance (Commonwealth of Australia 1994).

\section{Assistance for the low-paid and the unemployed}

Prior to 1945 , relief for 'able-bodied' unemployed people was undertaken by state governments, often in association with church charity agencies. Customary methods of assistance were through rations or sustenance. or by providing food or wages in return for relief work (Kewley 1969, p. 4; Cass 1988, pp. 11-12).

In 1945 the Commonwealth government introduced an unemployment benefits scheme. The structure of benefits embodied assumptions that:

- $\quad$ unemployed people would only be out of work for a short time;

- unemployed people would get a full-time job; and

- only one person in a couple would be actively looking for work with the other partner, usually the wife, being economically dependent (Cass 1998, pp.15-18).

Unemployment increased significantly during the recession of the early 1970s and despite high levels of economic growth in the subsequent recovery, high levels of unemployment persisted into the late 1970s and early $1980 \mathrm{~s}$. At the same time there was significant growth in part-time work. This led to successive liberalisations of the unemployment benefits income test from 1980 onwards to improve incentives for unemployed people to take up part-time and/or casual work.

The inevitable consequence of these changes was to increase the income cut-out point for benefits and thus to erode relative incentives to make the move from part-time to full-time work. By the late 1980 s concerns were again being raised about the relativities between unemployment benefits (especially when combined with part-time work) and the incomes of people in low-paid full-time work (Cass 1988, pp. 107-127, Whitlock 1994).

In July 1995, as part of the Working Nation policy package, substantial changes were made to the structure of income support for unemployed people, to improve work incentives and also to recognise the increasing labour force participation of women. The maximum withdrawal rate for benefits (by then called allowances) was reduced from 100 per cent to 70 per cent. This aimed to ensure that people on unemployment payments would always increase their disposable income by earning more (Commonwealth of Australia 1994).

In 2005, the income test for allowance payments was further liberalised, this time as part of the Welfare to Work policy package. From this point on, it has been possible for people in the lowest-paid full-time jobs to receive income supplementation through Newstart Allowance, Australia's main unemployment payment.

\section{The historical relationship between wages and transfers}

\section{Unemployment benefit and the minimum wage}

The relationship between minimum wages and the level of unemployment benefits is an important indicator of the incentive for unemployed people to take up low-paid work. Figure 2 shows a time series of the ratio between unemployment benefits and gross income at the Federal Minimum Wage (FMW) equivalent ${ }^{6}$, from the introduction of unemployment benefits in 1945 until 2008. 
Figure 2: Ratio of unemployment benefits to gross income* at FMW-equivalent wage, single adult and couple with three children, 1946 to 2008

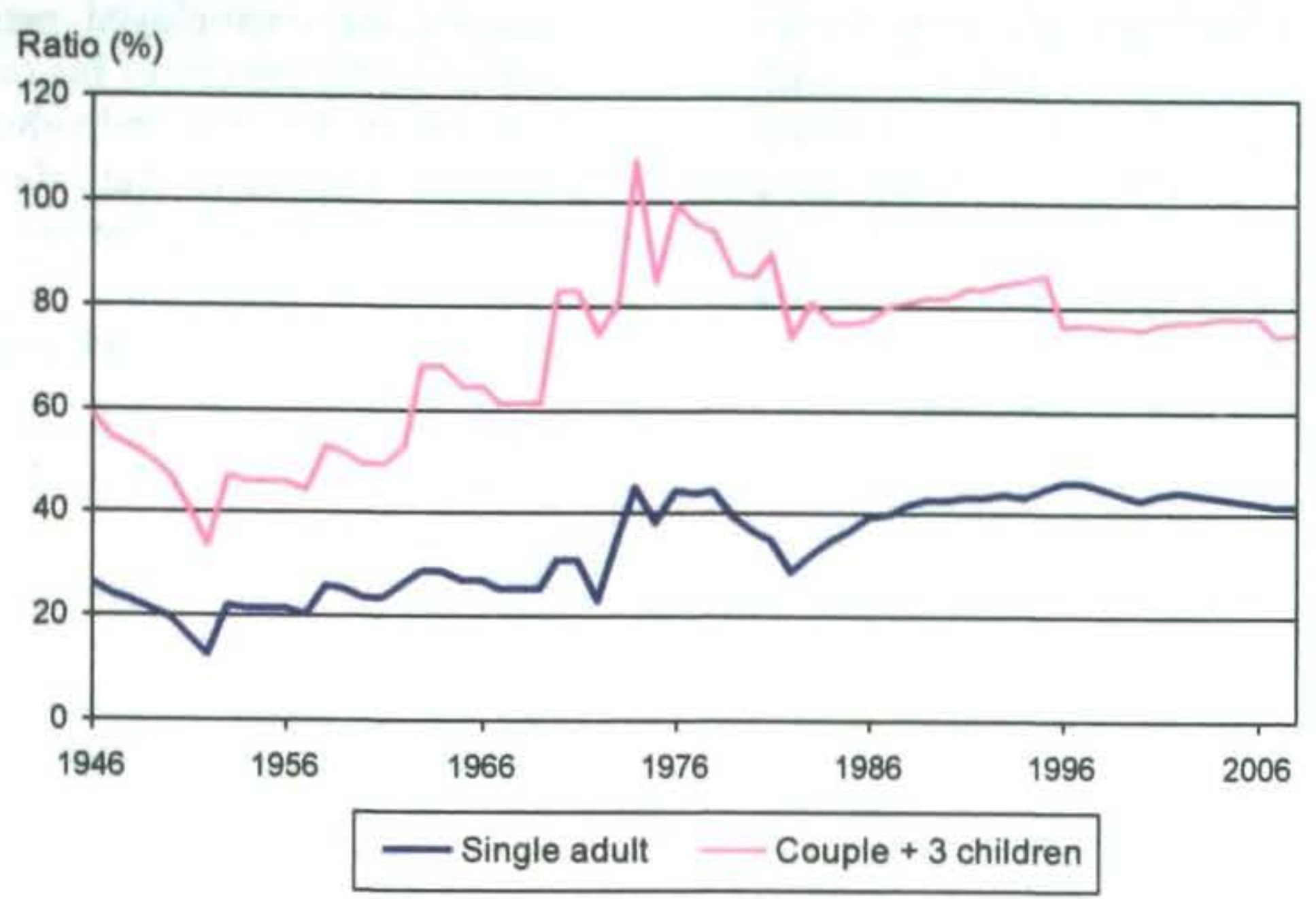

*Gross income at minimum wage includes any available income transfers, where applicable.

The replacement rates modelled here, for a single adult without children and a single-earner 'Harvester' family of two adults and three children, are not true replacement rates as the financial modelling does not take account of income tax. Nevertheless, they provide a reasonable proxy for trends in replacement rates over that period.

As Figure 2 shows, financial incentives for single people to take up low-paid employment have always been strong, with the gross replacement rate rarely exceeding 45 per cent. For families with children, however, it has been a different story, with the gross replacement rate climbing steadily through the 1960 s and 1970 s, to a point where for larger family types it was briefly higher than 100 per cent.

The cumulative effects of the changes to family assistance since 1983 and unemployment benefits since the mid-1990s have helped to reduce the gross replacement rate for a couple with three children to less than 80 per cent, where it has been relatively stable over the past decade or so.

\section{Overlap between income support and minimum wages}

Figure 3 illustrates an alternative perspective on the work incentive effects of unemployment benefits and minimum wages. It charts the ratio of the cut-out point for benefit (the amount of gross income at which benefit entitlement is lost under the income test) to the FMW-equivalent wage. This ratio is especially indicative of incentives to work full-time relative to working part-time and continuing to receive income support.

For a single adult, there has been a steady increase in the ratio, as the income test for unemployment benefits has been eased. Significant increases are associated with the Working Nation changes in 1996 and with Welfare to Work in 2006.

Figure 3: Ratio of income support cut-out point to FMW-equivalent wage, single adult and partnered person with three children, 1946 to 2008

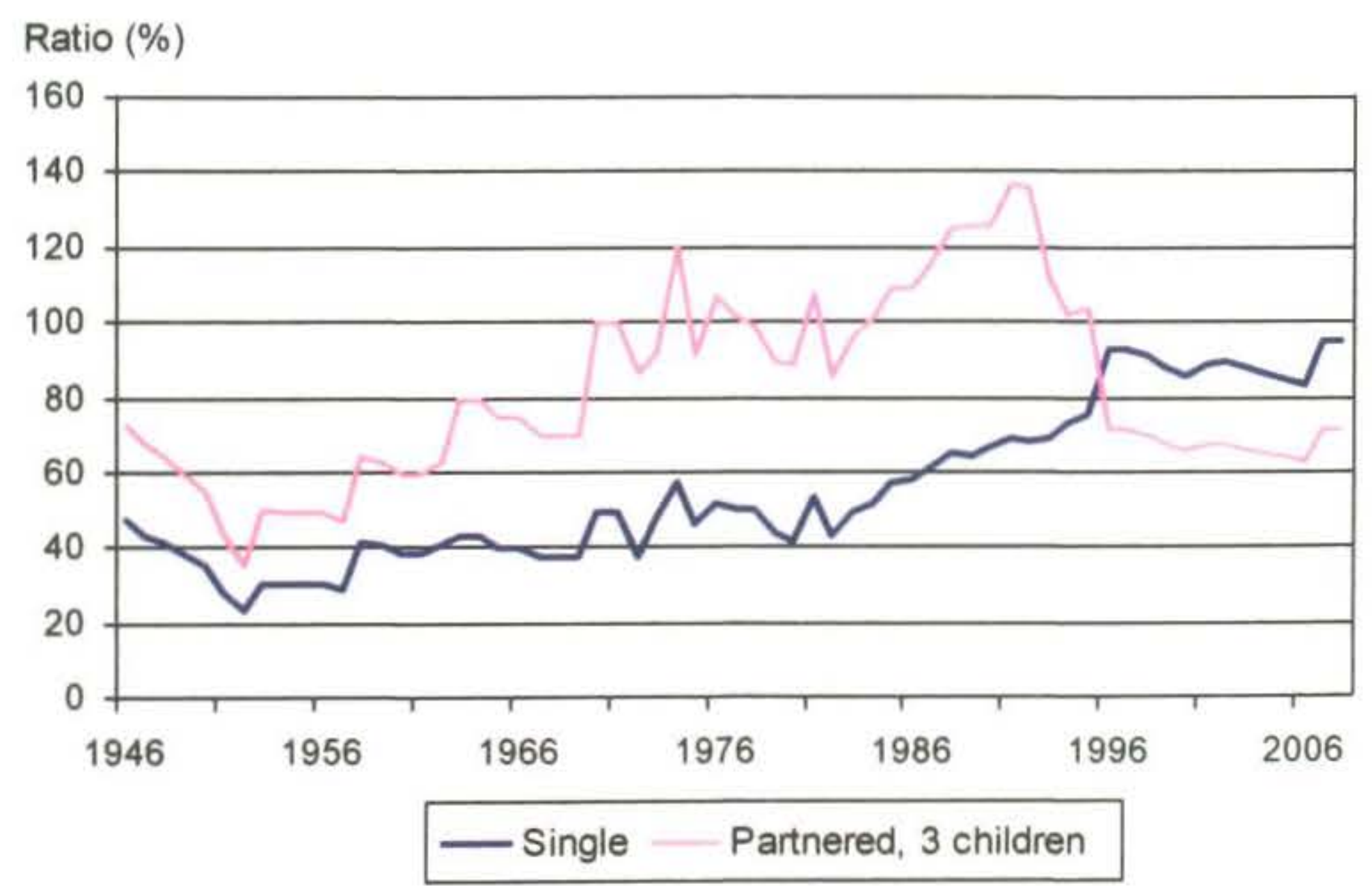


For the partnered beneficiary, on the other hand, the combination of a benefit that included payments for an unemployed spouse and three children with improvements in the income test meant that, consistently from about 1985 onwards, a person taking a full-time low-wage job could be financially worse off than someone working part-time at a higher hourly wage and retaining entitlement to a part-rate benefit. This situation was remedied through two major policy changes.

- The first step involved transferring child payments to the primary carer in 1993 . This significantly reduced the amount of unemployment benefits payable to the breadwinner and also improved the financial transition into work, by providing continuity of assistance for children.

- The second, more significant, change was the disaggregation of benefits in 1995, which meant that the partner of an unemployment beneficiary could claim and receive a payment in their own right. Because income from work was offset first against the unemployed person's benefit before reducing the benefit of his or her partner, the cutout point for the individual fell dramatically, despite the fact that the income test was significantly eased at the same time.

\section{Real gross income at FMW-equivalent wages}

Figure 4 shows the cumulative effect of all of these developments in the social security system on the real gross incomes of families on FMW-equivalent wages. For both the single adult and the family of five, there was a consistent upward trend until the early 1980s. Through all that earlier time period the gross income for the family was only marginally higher than that of a single adult. Since the mid-1980s, however, the gross income for a single minimum wage-earner has been roughly stable in real terms, but the real income of the family of five has increased by around 60 per cent.

Figure 4: Real gross income at FMW-equivalent wages, single adult and couple with three children, 1949 to 2008

$\$ p w(2008 \$)$

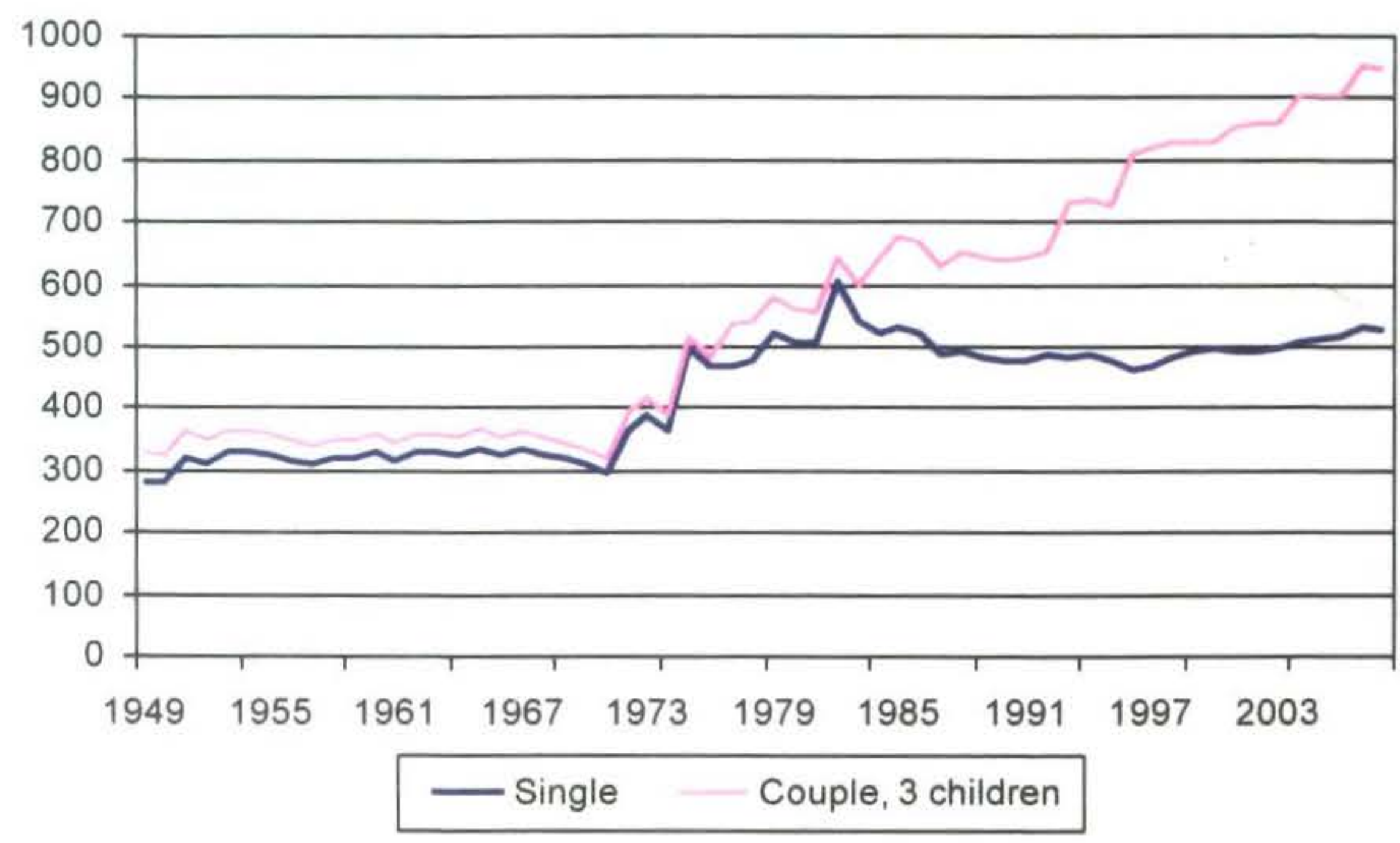

Source: AFPC Modelling

\section{Current interactions between wages and transfers}

The next two figures illustrate how earnings and income support payments combine for workers with varying levels of earnings. The cases modelled are a single person without children (Figure 5) and a single-earner couple with three children (Figure 6), both assumed to be paying sufficient private rent to receive maximum rent assistance.

For a single person, income support when out of work is a little under $\$ 15,000$ a year. This tapers out steadily as earnings rise to an annual income of around $\$ 26,700$, about $\$ 1,600$ a year below the current level of the FMW. 
Figure 5: Components of disposable income, single adult, September 2008



Source: AFPC Modelling

The picture is considerably more complex for the couple with three children, depicted in Figure 6. When out of work, this family is entitled to:

- $\quad$ income support for the first partner;

- $\quad$ income support for the second partner; and

- Family Tax Benefit Parts A and B.

All of these benefits can be retained to some degree when one partner moves into low-paid employment. The partner moving into work retains a part-rate of income support until earnings reach around $\$ 19,500$. Meanwhile, the non-working partner retains income support until earnings reach around $\$ 37,500$.
Family Tax Benefit Part A (FTBA), the per-child component of FTB, is paid at maximum rates until annual earnings are more than $\$ 42,600$, about 50 per cent more than the annual FMW. The family also receives Family Tax Benefit B (FTBB), a payment made when one partner earns less than around $\$ 23,000$ a year.

As Figure 6 shows, a single-earner family with three children and one earner on the FMW of just over $\$ 28,000$ a year derives about half of its household income from social security transfers (around $\$ 5,500$ a year in income support for the parent and over $\$ 20,000$ in family tax benefits). This contrasts with the single adult on the FMW, where all income is derived from private earnings.

Figure 6: Components of disposable income, single-earner couple with 3 children, September 2008

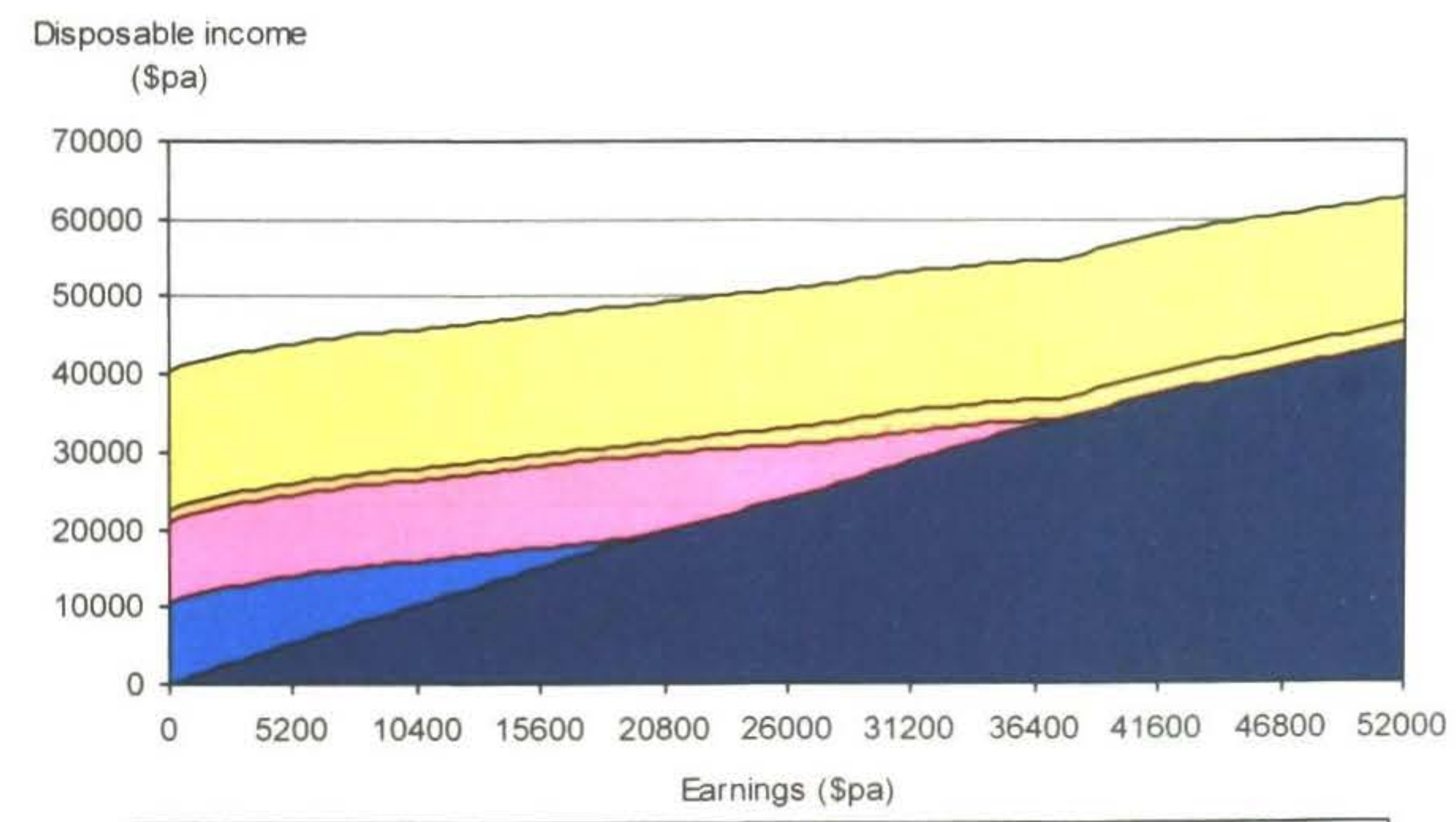

- Net earnings $\square$ P1 Income support $\square$ P2 Income support $\square$ FTBB $\square$ FTBA 


\section{How Australia compares with other OECD countries}

In this paper we have outlined how Australia has evolved a complex system of income supplementation for individuals in low-paid work. In its recent surveys of wages and benefit structures across the developed world, the OECD has found that a small number of mostly English-speaking countries (Australia and New Zealand, along with the United Kingdom (UK), Poland and Ireland) consistently provide the highest relative incomes to minimum-wage-earning households.

Table 1 summarises information from the recent OECD (2007) publication, Benefits and Wages 2007, which compares wages and benefit systems across OECD member countries. The table reports the results of disposable income modelling for three family types with one person earning the relevant country's statutory minimum wage - a single adult, a single parent with two children and a couple with two children. The primary measure is equivalised household disposable income relative to median equivalised household disposable income for the country as a whole. The five countries which consistently rank in the top five are highlighted in the table.
In both New Zealand and Australia a single person on the minimum wage in 2005 had disposable income of around 80 per cent of the median in equivalised terms. This is no doubt related to the fact that these two countries have among the highest minimum wages in OECD countries (AFPC 2008, Appendix D, pp. 107-110).

The analysis also shows that, with few exceptions, single adults on minimum wages have higher relative incomes than the other family types. In the highest ranked countries, equivalised incomes range, for the single parent family, from 64 per cent of the median in New Zealand to 93 per cent in the UK and, for the couple, from around 55 per cent in New Zealand to 82 per cent in the UK. Australia and the UK have the smallest differences across the three family types.

Bearing in mind that a commonly accepted poverty line used by the OECD is 60 per cent of median equivalised household income, these data show that the UK, Australia and Ireland consistently provide minimum wage earners with disposable incomes at or above this line. Poland and New Zealand do well in relation to single adults, but are less generous to low-paid families with children.

Table 1: Net incomes of full-time minimum wage earners as percentage of median household income and associated country ranking, various OECD countries, 2005

\begin{tabular}{|c|c|c|c|}
\hline \multirow{3}{*}{ Country } & \multicolumn{3}{|c|}{ Family type } \\
\hline & Single adult & $\begin{array}{c}\text { Single parent, two } \\
\text { children }\end{array}$ & Couple, two children \\
\hline & $\%$ of median (rank) & $\%$ of median (rank) & $\%$ of median (rank) \\
\hline Australia & 79.2 (3) & 88.0 & 74.8 (2) \\
\hline Belgium & $64.0 \quad(10)$ & $49.7 \quad(11)$ & $47.1 \quad(10)$ \\
\hline Canada & $46.9 \quad(17)$ & $47.7 \quad(12)$ & $42.7 \quad(14)$ \\
\hline Czech Republic & $52.8 \quad(14)$ & $53.1 \quad(9)$ & $53.2 \quad(7)$ \\
\hline France & $71.5 \quad(6)$ & $52.2 \quad(10)$ & $45.4 \quad(13)$ \\
\hline Greece & $69.1 \quad(8)$ & $42.1 \quad(14)$ & $36.4 \quad(15)$ \\
\hline Hungary & $60.5 \quad(11)$ & $55.8 \quad(7)$ & $47.0 \quad(11)$ \\
\hline Ireland & $73.6 \quad(5)$ & $76.7 \quad(3)$ & $60.0 \quad(3)$ \\
\hline Japan & $53.6 \quad(13)$ & $58.0 \quad(6)$ & $53.3 \quad(6)$ \\
\hline Luxembourg & $50.2 \quad(15)$ & $45.5 \quad(13)$ & 52.5 \\
\hline Netherlands & $68.4 \quad(9)$ & $55.6 \quad(8)$ & 47.2 \\
\hline New Zealand & $82.1 \quad(2)$ & $63.8 \quad(5)$ & $54.5 \quad(5)$ \\
\hline Poland & $78.3 \quad$ (4) & $69.6 \quad$ (4) & 58.0 \\
\hline Portugal & $55.6 \quad(12)$ & $38.9 \quad(16)$ & $45.5 \quad(12)$ \\
\hline Spain & $48.8 \quad(17)$ & $30.7 \quad(18)$ & $26.6 \quad(18)$ \\
\hline Turkey & $70.9 \quad(7)$ & $40.9 \quad(15)$ & $35.5 \quad(16)$ \\
\hline United Kingdom & $95.1 \quad$ (1) & $93.0 \quad(1)$ & $81.9 \quad(1)$ \\
\hline United States & $34.8 \quad(18)$ & $36.0 \quad(17)$ & $34.5 \quad(17)$ \\
\hline
\end{tabular}

Source: OECD Wages and Benefits 2007; see Statlink http://dx.doi.org/10.1787/141016253821

It must be acknowledged that only countries with statutory minimum wages are compared in Table 1 . Others, such as the Nordic countries, which nevertheless have well-regulated and relatively high wages, are not represented here. However, other OECD data show that the top-ranked countries in relation to minimum wage earners also tend to offer more generous basic levels of social assistance. For example, the UK also ranks first in terms of the level of out-of-work income as a proportion of median equivalised income and, while Australia is ranked tenth for assistance to single adults, it is ranked third and second, respectively, for its levels of assistance to single parents and couples with children (OECD 2007, pp.77-79). 


\section{Conclusion}

Over the last century, and even more so over the past twenty-five years, the Australian wages and benefits systems have been in a more or less continuous state of evolution. In recent years, particular attention has been paid to the need to provide adequate incentives for unemployed and other jobless people to take up paid work.

Australia has moved from the situation where the welfare needs of low-skilled workers and their families were largely met through the level of their wages to one in which the living standards of low-wage earners are supported through both minimum wages that are relatively generous in international terms and a comprehensive set of income transfers. In combination, Australia's minimum wage and social security system now deliver relative disposable incomes for low-wage workers that are among the highest in the developed world.

\section{Notes}

1. With the exception of 'junior' workers and those to whom training arrangements apply who were award free prior to 2006. The AIRC retained a transitional wage-setting function for employees who prior to 2006 had been in the federal jurisdiction and covered by the then Constitutional conciliation and arbitration head of power but after 2006 could not be covered by the Constitutional corporations head of power.

2. Commonwealth Court of Conciliation and Arbitration and various state wage-setting tribunals

3. The Five Economists (Peter Dawkins, John Freebairn, Ross Garnaut, Michael Keating and Chris Richardson) wrote an open letter to the Australian Prime Minister in October 1998, suggesting a freeze on wage adjustments, combined with appropriate tax credits for lowwage earners in low-income families (Dawkins 2002, p. 1).

4. The AIRC retained a transitional wage-setting function for employees who prior to 2006 had been in the federal jurisdiction covered by the then Constitutional conciliation and Arbitration head of power but after 2006 could not be covered by the Constitutional corporations head of power.

5. Until July 1950 child endowment was not paid for the first child in a family. It is interesting to note that, almost coincident with the introduction of child endowment, the Basic Wage Inquiry 194041 delivered a judgement that found the basic wage was adequate only to support a family of three (two adults and one child) (Kewley 1980, p. 91).
6. As no single FMW existed until 2006 , a variety of benchmarks have been used to compile a series of FMW-equivalent wages - for example, the average of State basic wages and the wage specified in the Federal Metal Industry Award for an unskilled (classification C14) employee. This latter was widely regarded as the de facto FMW immediately prior to 2006.

\section{Disclaimer}

Any conclusions drawn and opinions expressed in this paper are those of the authors and should not be taken to represent the conclusions or opinions of the Australian Fair Pay Commission or its Secretariat.

\section{References}

Apps, P. (2002a). Why the Five Economists' Plan for a "Wage-Tax Trade-off" is a Mistake for Australia. Canberra: Centre for Economic Policy Research, Australian National University, CEPR Discussion Paper No. 446.

Apps, P. (2002b). Comment on The 'Five Economists' Plan: The Original Idea and Further Developments. Canberra: Centre for Economic Policy Research, Australian National University, CEPR Discussion Paper No. 451.

Australian Fair Pay Commission (AFPC) (2008). Wage-Setting Decision and Reasons for Decision, July 2008. Melbourne: Commonwealth of Australia.

Australian Industrial Relations Commission (AIRC) (2005). Historical Overview. Melbourne: AIRC.

Australian Treasury (2008). Architecture of Australia's tax and transfer system. Canberra: Commonwealth of Australia.

Borland, J. (2002). Comment on The 'Five Economists' Plan: The Original Idea and Further Developments. Canberra: Centre for Economic Policy Research, Australian National University, CEPR Discussion Paper No. 451.

Cass, B. (1988). Income Support for the Unemployed in Australia: Towards a More Active System. Canberra: Australian Government Publishing Service, Social Security Review Issues Paper No. 4.

Commonwealth of Australia (1994). Working Nation, Policies and Programs. Canberra: Australian Government Publishing Service.

Creighton, B. and Stewart, A. (2005). Labour Law, Fourth Edition. Sydney: The Federation Press. 
Daprè, B. (2006a). A Compendium of Legislative Changes in Social Security 1983-2000, Part 1 1983-1993. Canberra: Australian Government, Department of Families, Community Services and Indigenous Affairs, Occasional Paper No 13.

Daprè, B. (2006b). A Compendium of Legislative Changes in Social Security 1983-2000, Part2 1994-2000. Canberra: Australian Government, Department of Families, Community Services and Indigenous Affairs, Occasional Paper No 13.

Dawkins, P. (1999). A Plan to Cut Unemployment in Australia: An Elaboration on the 'Five Economists' Letter to the Prime Minister, $28^{\text {th }}$ October 1998'. Mercer-Melbourne Quarterly Bulletin of Economic Trends, 1, 48-57.

Dawkins, P. (2002). The 'Five Economists' Plan: The Original Idea and Further Developments. Canberra: Centre for Economic Policy Research, Australian National University, CEPR Discussion Paper No. 450.

Department of Families, Community Services and Indigenous Affairs (FaCSIA) (2006). A Compendium of Legislative Changes in Social Security 1908-1982. Canberra: Australian Government, Department of Families, Community Services and Indigenous Affairs, Occasional Paper No 12.

Department of Social Security (DSS) (1993). Meeting the Challenge: Labour Market Trends and the Income Support System. Canberra: Australian Government Publishing Service. Department of Social Security Policy Discussion Paper No. 3.

Douglas, S., Groth, A. and Pech, J. (1993). Dependency-based Payments: married Women in the Social Security System. Canberra: Australian Government Publishing Service, Department of Social Security Policy Discussion Paper No. 1.

Hancock, K. J. (1979a). The First Half-Century of Australian Wage Policy - Part I. The Journal of Industrial Relations, March 1979, 1-19.

Hancock, K. J. (1979a). The First Half-Century of Australian Wage Policy - Part II. The Journal of Industrial Relations, June 1979, 129-160.

Hancock, K. (2004). The Wage of the Unskilled Worker and Family Needs, 1907 and 1920. Adelaide: National Institute of Labour Studies, Working Paper Series, No. 152.
Harding, A. and Richardson, S. (1999). The Lowly Paid, the Unemployed and Family Income. Australian Journal of Labour Economics, 3(1), 23 . 46.

Kewley, T.H. (1969). Australia's Welfare State. South Melbourne: Macmillan of Australia.

Kewley, T.H. (1980). Australian Social Security Today. Sydney: Sydney University Press.

Nieuwenhuysen, J. (1974). The National Wage Case 1974. The Journal of Industrial Relations, September 1974, $284-290$.

Organisation for Economic Co-operation and Development (OECD) (2007). Benefits and Wages 2007: OECD Indicators. Paris: OECD Publishing.

Owens, R. and Riley, J. (2007). The Law of Work. South Melbourne: Oxford University Press.

Whiteford, P. and Angenent, G. (2001). The Australian system of social protection - an overview, Second Edition. Canberra: Australian Government, Department of Families, Community Services and Indigenous Affairs, Occasional Paper No 6.

Whitlock, B. (1994). Does the Social Security Income Support System Remove the Incentive to Work? Canberra: Australian Government Publishing Service, Department of Social Security Policy Discussion Paper No. 4.

\section{Authors}

Sarah Wilkin

Research Analyst

Australian Fair Pay Commission Secretariat

Melbourne

Victoria

Australia

Sarah.Wilkin@fwa.gov.au

Jocelyn Pech

Manager of Safety Net Analysis

Australian Fair Pay Commission Secretariat

Melbourne

Victoria

Australia

Jocelyn.Pech@fwa.gov.au 